\title{
The Early Career Paths and Employment Conditions of the Academic Profession in 17 Countries
}

\author{
ALICE BENNION and WILLIAM LOCKE \\ Centre for Higher Education Research and Information (CHERI), The Open \\ University, UK. E-mail: A.Bennion@open.ac.uk; W.D.Locke@open.ac.uk
}

The expansion of higher education systems, new demands on institutions and growing pressures on resources have become common trends across most developed countries. They bring increased expectations of academic staff and appear to lead to greater differentiation in their work roles and activities. At the same time, the backgrounds of some academics are changing and they are developing new specialisms and interdisciplinary collaborations, becoming more mobile domestically and internationally and, for some, the profession is becoming increasingly insecure. The Changing Academic Profession study has produced a rich set of data on the preparation of academics for their roles and the individual circumstances of their working lives, among other aspects of the profession. Respondents to the survey reported on the degrees they have attained, the countries in which they studied for them, the age at which they qualified and the nature of the doctoral training they received. This paper explores the early career paths of academics, makes initial comparisons between different higher education systems and begins to explore how some of these national systems interrelate with each other through academic mobility. Respondents also reported on the disciplines they studied and now teach, the number of institutions worked in and their contractual conditions and income. These data give an indication of the various degrees of flexibility and mobility required of - or chosen by - academics in the early and later stages of their careers and the stability, or perhaps rigidity, of different higher education systems and national career patterns. The data also supplement other evidence of the employment conditions and remuneration of scholars in an increasingly globalised academic labour market. ${ }^{1,2}$ The conditions of academic work are explored through analysis of the views of survey respondents on the facilities, resources and 
personnel needed to support it and the degree of research collaboration undertaken. Academics from the 17 countries in the study seem more content with the physical and technical resources provided by their institutions than the personnel and funds available to support teaching and research. Finally, it is suggested that the propensity for collaborative or individual research may be partially related to national differences in academics' mobility during their training for the profession.

\section{Introduction}

The expansion of higher education systems, new demands on institutions and growing pressures on resources have become common occurrences in developed countries. These trends bring increased expectations of academic staff: to be more highly qualified, international in outlook, dynamic and useful to the wider society. They also appear to lead to greater differentiation in academics' work roles and activities, as distinctions emerge between different disciplines, types of institutions within national higher education systems, and grades or ranks in the profession. At the same time, the backgrounds of some academics are changing and they are developing new specialisms and interdisciplinary collaborations, becoming more mobile domestically and internationally and, for some, the profession is becoming increasingly insecure.

The Changing Academic Profession (CAP) survey has produced a rich set of data on the preparation of academics for their roles and the individual circumstances of their working lives, among a range of aspects of the profession, some of which are covered by other contributors to this special issue of the European Review. Respondents to the survey reported on the degrees they have attained, the countries in which they studied for them, the age at which they qualified and the nature of the doctoral training they received. The first part of this paper deals with the early career paths of academics, makes tentative comparisons between different higher education systems and begins to explore how some of these national systems interrelate with each other through academic mobility.

Respondents to the (CAP) survey also reported on the number of institutions worked in and their contractual conditions and income. These data give an indication of the various degrees of flexibility and mobility required of - or chosen by academics in the early and later stages of their careers and the stability, or perhaps rigidity, of different higher education systems and national career patterns. These data also supplement other evidence of the employment conditions and remuneration of scholars in an increasingly globalised academic labour market.

The circumstances of academic work are also explored in the paper through analysis of the views of survey respondents on the facilities, resources and personnel needed to support their research and teaching activities. Finally, the degree of respondents' research collaboration with academics at other institutions 
within the same country and with international colleagues is evaluated. To provide a historical perspective where relevant, comparisons are made with the earlier Carnegie Foundation international study of the academic profession, 3,4 undertaken in 1992, and including nine of the 17 countries that have provided data for the CAP study so far.

\section{The early career paths of academics}

Countries vary widely in their structure, provision and support of higher education and this is reflected in the early career paths of academics, the qualifications obtained, the country of study and their experiences of doctoral degree training. This paper concentrates mainly on academics' doctoral training as the data linked to First, Second and Postdoctoral degrees are less easily comparable due to differences in each country's higher education system. Some of these differences will be discussed in this paper.

\section{Degrees obtained}

Differences in higher education systems are reflected in the qualifications that academics claim to hold. Finland and Norway, for example, are the only countries where more respondents report holding a Second degree than a First degree. Before the Bologna Process introduced a three-cycle higher education qualification system, parts of continental Europe did not have a First degree 'stopping off' point, and students progressed to a Master's (i.e. a Second degree in terms of the CAP survey) without gaining a Bachelors degree, hence the apparent low proportions of those respondents with a 'First degree'. The number of academics in the UK and Germany who report having a Second degree is lower than most of the other countries surveyed. Once again this can be explained by differences in higher education systems. In some disciplines in the UK, for example, students have been able to progress directly from a first degree onto a doctoral program, although this has become less common.

Table 1 focuses on doctoral degrees. It should be noted that not all respondents who reported obtaining a doctoral degree identified their academic rank.

The responses suggest that more mature higher education systems (e.g. Canada and the US) tend to have a higher proportion of academics with $\mathrm{PhDs}$ than the emerging/rapidly expanding systems (e.g. Mexico and Argentina). Apart from one country, the percentage of junior staff holding a doctoral degree is lower than among senior staff. Italy is the only country where the percentage of senior academics holding a doctoral degree is lower than that of junior staff because doctoral programmes were not established until 1980 and the second cycle of the Bologna Process was introduced in 2000. The differences between the proportions of junior and senior respondents obtaining a doctoral degree 
Table 1. Percentage of respondents obtaining a doctoral degree, by country and seniority

MX AR CH MY FI IT BR NO PT AU UK DE JP HK US CA KR

$\begin{array}{llllllllllllllllll}\text { All Staff } & 29 & 32 & 32 & 37 & 45 & 48 & 58 & 60 & 72 & 73 & 73 & 78 & 78 & 82 & 83 & 92 & 97 \\ \text { Senior Staff } & 36 & 37 & 49 & 73 & 86 & 34 & 75 & 85 & 97 & 92 & 90 & 98 & 78 & 93 & 91 & 94 & 98 \\ \text { Junior Staff } & 14 & 29 & 17 & 29 & 33 & 69 & 38 & 37 & 82 & 72 & 80 & 67 & 76 & 73 & 71 & 88 & 97\end{array}$

Country key: $\mathrm{AU}=$ Australia; $\mathrm{AR}=$ Argentina; $\mathrm{BR}=$ Brazil; $\mathrm{CA}=$ Canada;

$\mathrm{CH}=$ China; $\mathrm{DE}=$ Germany; FI = Finland; HK = Hong Kong; IT = Italy; JP = Japan;

$\mathrm{KR}=$ South Korea; MX = Mexico; MY = Malaysia; NO = Norway; PT = Portugal;

$\mathrm{UK}=$ United Kingdom; US = United States of America.

appear widest in Finland, Norway, Malaysia and China. This is because, within these systems, individuals can train for the doctorate whilst holding a junior post at a university. In Norway and Finland, for example, doctoral candidates are not given the formal status of 'student' and are therefore considered junior members of academic staff and included in the country's sample. In South Korea and Canada, it seems that holding a doctorate has virtually become a minimum threshold for new entrants to the profession. In several other mature systems, this also appears to be true for senior positions.

Given the emergence of a global higher education market, the internationalisation of students and academic staff has become more widespread. In the majority of countries, those obtaining their First degree from another country are less than 15\% of the total. Of the six countries with more than $15 \%$, four are Commonwealth countries (Australia, Canada, Malaysia and the UK) and one (Hong Kong) was a British territory until 1997. Latin American and Asian countries (China, South Korea, Japan, Brazil, Argentina and Mexico) tend to have the smallest proportions of academics with First degrees from other countries (although Italy has the second lowest proportion). Hong Kong is the only territory that has a minority of academics who obtained their First degree from within the territory.

Table 2 shows the proportions of those respondents in each country who obtained their doctoral degree in the same country. Again, it should be noted that not all staff who reported where they obtained a doctoral degree also identified their academic rank.

Hong Kong and Malaysia are the only two countries where less than $50 \%$ of academics surveyed obtained their doctoral degrees within the country in which they are currently working. For senior members of staff in these two countries the percentages are even lower (17\% and 28\%). In Malaysia, universities prefer to employ senior members of academic staff that have obtained their $\mathrm{PhD}$ abroad, especially if they have studied for a Masters and First degree locally. This is 
Table 2. Percentage of respondents obtaining a doctoral degree in the country of current employment

HK MY KR MX CA NO AU PT IT AR UK BR FI DE CH US JP

$\begin{array}{lrllllllllllllllll}\text { All Staff } & 26 & 37 & 55 & 59 & 68 & 68 & 74 & 74 & 82 & 83 & 85 & 86 & 91 & 91 & 94 & 94 & 96 \\ \text { Senior Staff 17 } & 28 & 53 & 66 & 67 & 83 & 61 & 66 & 71 & 77 & 87 & 84 & 91 & 91 & 93 & 93 & 95 \\ \text { Junior Staff } & 35 & 47 & 59 & 40 & 68 & 47 & 75 & 81 & 92 & 87 & 82 & 92 & 90 & 91 & 95 & 94 & 100\end{array}$

Table 3. Country where doctoral degree obtained: percentage of respondents in selected countries

\begin{tabular}{lllllllll}
\hline $\begin{array}{l}\text { Hong Kong } \\
\text { Hong Kong }\end{array}$ & Japan & Germany & China & Other & Canada & Australia & UK US \\
\hline 27 & 1 & 2 & 2 & 3 & 6 & 10 & 22 & 29 \\
\hline $\begin{array}{l}\text { Malaysia } \\
\text { Malaysia }\end{array}$ & Canada & Japan & Other & Australia & US & UK & & \\
\hline 40 & 1 & 2 & 4 & 5 & 11 & 37 & \\
\hline
\end{tabular}

\begin{tabular}{lllllllll}
\hline $\begin{array}{l}\text { Korea } \\
\text { Korea }\end{array}$ & UK & China & Other & Japan & Germany & US & & \\
\hline 57 & 1 & 1 & 2 & 4 & 5 & 30 & & \\
\hline $\begin{array}{l}\text { Mexico } \\
\text { Mexico }\end{array}$ & Italy & Japan & Germany & Brazil & Canada & UK & US & Other \\
\hline 59 & 1 & 1 & 1 & 1 & 2 & 5 & 12 & 18 \\
\hline \hline
\end{tabular}

especially true in science and technology related fields, where studying abroad is believed to broaden networks and prevent parochial cultures. As the paper discusses in detail below, Hong Kong attracts large numbers of academic staff who have trained elsewhere, predominately within the United States (see Table 3).

Apart from Mexico, Norway and the UK, the percentage of junior staff holding a doctoral degree from the country in which they are currently employed is higher than it is for senior members of staff. This suggests that doctoral students in these countries obtain junior posts within the national higher education system in which they have been trained. In Finland, Germany and the US 
there is less than a 5\% difference between senior and junior staff obtaining their doctoral degree in the country of current employment. As discussed below, this reflects the nature of these countries' higher education systems as attractors and/ or retainers of both students and staff.

Only Hong Kong and Malaysia have a minority of academics who obtained their Doctoral degrees within the country, and the vast majority of the remainder obtained them in the UK and the US.

Those working in the US, Finland, Australia and the UK are more likely to have obtained their Doctoral degree and their First degree from the country in which they are currently working. Most academics working in Japan and China have obtained their First, Second and Doctoral degrees within their country of current employment. Finland and Italy are not far behind.

We might summarise the characteristics of academic flows between (and within) national higher education systems as follows:

(a) 'Study abroad' - the movement of individuals out of a national higher education system to undertake doctoral training abroad before re-entering the system for postdoctoral study and/or employment.

(b) 'Magnetic' - the flow of academics to a higher education system for study, work or both.

(c) 'Self-contained' - the internal movement of academic staff from study to employment within a single higher education system.

Countries can display one or more of these characteristics. For example, the US and UK higher education systems attract individuals to study and work whilst also exhibiting a strong self-contained domestic labour market. The influence of North American universities as 'people attractors' is well documented. ${ }^{5-8}$ North American institutions are 'open and flexible, provide superior scholarship and salaries' and are thus 'extraordinary global attractors of talent'. 'Foreign doctoral assistants have become essential to American research; the United States is the main site for postdoctoral places and short-term academic visits, and also draws later career migration'. ${ }^{6}$ Welch describes the US and the UK as major 'producers and exporters of academic labour'. ${ }^{8}$ Yet, there is also a large majority of academics who complete their training in these countries and remain employed within the national system.

In other countries, one characteristic tends to predominate. In the case of Korea and Mexico this is 'Study abroad'. It appears that significant proportions of Korean and Mexican academics study for their doctorates outside of these countries (mainly in the US) and then return to take up academic employment and, in the case of Korea, postdoctoral study. In the survey, 99\% of Korean academics listed their current country of citizenship as the Republic of Korea. Ninety-eight percent of academics working in Korea completed their first degree 
in the country, whilst only $55 \%$ had undertaken doctoral studies within Korea. Eighty-nine percent of Korean academics had completed postdoctoral study within the country, which suggests an outward movement at the doctoral level. This situation has been driven by the limited educational choices and a strong public demand for the best education possible, which has not been satisfied domestically. ${ }^{9}$ In Mexico, barely 1000 students were enrolled in Mexican PhD programs in 2001 compared with 45,000 in the US. ${ }^{10}$

The international recruitment of staff in Hong Kong makes it a major importer of talent: the dominant academic flow can be characterised as 'magnetic'. However, the high proportion of doctorates obtained outside the country is a significant reduction from the earlier Carnegie survey. Nevertheless, the majority of Hong Kong academics who originated in mainland China obtained their doctorates in the US or elsewhere. ${ }^{11}$ Japan, China and Italy are examples of 'selfcontained' systems with the majority of academics stating they completed their studies in the country in which they are now working. These countries are either more ethnically homogeneous, do not use English as a language of instruction, and/or have a relatively small range of other countries to draw upon that speak their language. ${ }^{6}$

\section{Age when degrees obtained}

Academic respondents in English-speaking and Asian countries obtained their First degree at a younger age than their counterparts in continental Europe and Latin America. However, in 14 of the 17 countries, the age range is only between 23 and 25 years of age. The variation among all countries in ages for First degrees obtained (4 years) is far narrower than for Second degrees (13 years) and Doctoral degrees (8.5 years). Those in the English-speaking countries, and especially the UK, completed their training earlier than other countries partly because the training is shorter. In England and Wales, for example, First Degrees have tended to consist of three years full-time study, and, throughout the UK, a Master's programme is one year full-time study. Doctoral study is nominally three years full-time study. The duration between obtaining the First and a Doctoral degree is shorter for academics in Italy and Germany than for their counterparts in other countries, including the English-speaking countries. In Italy, for example, first degrees are long degrees and doctoral degrees have a fixed length of three years.

\section{Preparation for the academic profession}

The nature and quality of graduate and doctoral education has come under increasing scrutiny in recent years, not only as training for highly skilled occupations beyond the academy, but also for careers in the academic profession itself. $^{12}$ The forms, duration, funding and status of doctoral programmes vary 
considerably. In many Western and Northern European countries (although not the UK), for example, doctoral candidates are regarded as junior or assistant researchers and not considered to be students, as mentioned above.

The majority of academics in each country chose their own research topic (Table 4). In all the countries, the vast majority of academics were required to write a thesis or dissertation. Significantly fewer respondents in China and Japan, however, were required to do this, it seems.

Higher proportions of academics in North and Latin America were required to take a prescribed set of courses than in Western Europe, where the master/ apprentice model still holds sway (Table 5). In Italy, for example, doctoral schools were only introduced in the mid-2000s. Academics in Asian and Latin American countries were more likely to have received intensive faculty guidance about their research than those in most European countries. However, Portugal and Italy are the outliers, with $92 \%$ and $82 \%$ of respondents, respectively, reporting this. A minority of academics in all countries received training in instructional skills or learned about teaching methods. This is the subject of a common complaint made by doctoral degree holders and highlights not only the narrowness of the curriculum but also the fact that doctoral programs provide virtually no training in pedagogy and offer limited opportunities to teach. ${ }^{13}$

The proportion of respondents receiving a scholarship or fellowship ranges from $21 \%$ (Germany) to $81 \%$ (Italy), with no obvious pattern. ${ }^{14}$ Likewise, the range of those in receipt of an employment contract during their studies ranges from $5 \%$ in Japan to $64 \%$ in Norway (Table 6).

A majority of academics in Latin American countries were involved in research projects with faculty or senior researchers, with a massive $86 \%$ in Argentina (Table 7). In all countries, a minority served on an institutional or departmental (unit) committee. Together with the limited training in pedagogy, this general lack of concern with the service role of an academic skews preparation for the profession throughout the CAP countries towards research and research-related activities.

Respondents in Latin and North American and continental European countries reported having worked in more institutions since their first degree than their counterparts in Asian countries, despite the younger age at which the latter obtain this degree (Table 8). 'Self-contained' academic labour markets may be characterised by fewer moves between institutions, especially in those systems, such as Japan, where institutional 'inbreeding' has been prevalent. ${ }^{15}$

\section{Employment conditions and pay}

The diversity of higher education, and the academic profession in particular, is highlighted by the range of conditions of employment and the forms of 
Table 4. Doctoral degree training: percentage of respondents agreeing, by country

\begin{tabular}{lccccccccccccccccc}
\hline & $\mathrm{CH}$ & $\mathrm{AR}$ & $\mathrm{DE}$ & $\mathrm{JP}$ & $\mathrm{IT}$ & $\mathrm{NO}$ & $\mathrm{UK}$ & $\mathrm{FI}$ & $\mathrm{MY}$ & $\mathrm{PT}$ & $\mathrm{CA}$ & $\mathrm{AU}$ & $\mathrm{BR}$ & $\mathrm{KR}$ & HK & US & MX \\
\hline $\begin{array}{l}\text { You chose your } \\
\text { own research } \\
\text { topic }\end{array}$ & 53 & 58 & 58 & 60 & 61 & 62 & 64 & 68 & 68 & 69 & 74 & 75 & 79 & 81 & 84 & 84 & 88 \\
\hline & $\mathrm{CH}$ & $\mathrm{JP}$ & $\mathrm{CA}$ & $\mathrm{FI}$ & $\mathrm{KR}$ & $\mathrm{MY}$ & $\mathrm{NO}$ & $\mathrm{IT}$ & $\mathrm{HK}$ & $\mathrm{PT}$ & $\mathrm{UK}$ & $\mathrm{US}$ & $\mathrm{AU}$ & $\mathrm{BR}$ & $\mathrm{MX}$ & $\mathrm{AR}$ & $\mathrm{DE}$ \\
\hline $\begin{array}{l}\text { You were required } \\
\text { to write a thesis } \\
\text { or dissertation }\end{array}$ & 79 & 83 & 90 & 93 & 95 & 95 & 95 & 96 & 97 & 97 & 97 & 97 & 98 & 98 & 98 & 99 & 100 \\
\hline
\end{tabular}


Table 5. Doctoral degree training: percentage of respondents agreeing, by country

\begin{tabular}{|c|c|c|c|c|c|c|c|c|c|c|c|c|c|c|c|c|c|}
\hline & $\mathrm{DE}$ & $\mathrm{AU}$ & UK & PT & MY & $\mathrm{JP}$ & IT & HK & FI & MX & $\mathrm{CA}$ & AR & $\mathrm{NO}$ & $\mathrm{CH}$ & KR & US & BR \\
\hline \multirow{2}{*}{$\begin{array}{l}\text { You were required to take a } \\
\text { prescribed set of courses }\end{array}$} & 15 & 16 & 19 & 22 & 34 & 36 & 51 & 54 & 64 & 68 & 69 & 70 & 70 & 73 & 81 & 83 & 87 \\
\hline & UK & $\mathrm{AU}$ & $\mathrm{DE}$ & NO & FI & MY & $\mathrm{CA}$ & HK & JP & AR & KR & BR & US & $\mathrm{CH}$ & IT & MX & PT \\
\hline \multirow{2}{*}{$\begin{array}{l}\text { You received intensive faculty } \\
\text { guidance for your research }\end{array}$} & 23 & 28 & 29 & 30 & 35 & 41 & 48 & 50 & 60 & 61 & 63 & 68 & 70 & 71 & 82 & 87 & 92 \\
\hline & $\mathrm{DE}$ & NO & $\mathrm{PT}$ & FI & $\mathrm{AU}$ & UK & JP & MY & BR & HK & $\mathrm{CA}$ & AR & $\mathrm{CH}$ & IT & KR & US & MX \\
\hline $\begin{array}{l}\text { You received training in instructional } \\
\text { skills or learned about teaching methods }\end{array}$ & 8 & 8 & 11 & 12 & 14 & 14 & 15 & 15 & 17 & 19 & 20 & 21 & 22 & 25 & 26 & 34 & 36 \\
\hline
\end{tabular}


Table 6. Doctoral degree training: percentage of respondents agreeing, by country

\begin{tabular}{|c|c|c|c|c|c|c|c|c|c|c|c|c|c|c|c|c|c|}
\hline & $\mathrm{DE}$ & $\mathrm{CH}$ & MX & JP & $\mathrm{PT}$ & HK & FI & BR & $\mathrm{KR}$ & $\mathrm{AR}$ & $\mathrm{AU}$ & UK & US & CA & MY & NO & IT \\
\hline \multirow{2}{*}{$\begin{array}{l}\text { You received a scholarship } \\
\text { or fellowship }\end{array}$} & 21 & 31 & 38 & 49 & 52 & 57 & 58 & 64 & 64 & 66 & 67 & 68 & 72 & 73 & 73 & 73 & 81 \\
\hline & $\mathrm{JP}$ & IT & PT & BR & UK & MY & MX & HK & $\mathrm{AU}$ & $\mathrm{CH}$ & FI & KR & $\mathrm{AR}$ & US & $\mathrm{CA}$ & $\mathrm{DE}$ & NO \\
\hline $\begin{array}{l}\text { You received an employment contract during } \\
\text { your studies (for teaching or research) }\end{array}$ & 5 & 18 & 25 & 27 & 33 & 34 & 35 & 38 & 39 & 39 & 47 & 51 & 53 & 57 & 59 & 63 & 64 \\
\hline
\end{tabular}


Table 7. Doctoral degree training: percentage of respondents agreeing, by country

\begin{tabular}{|c|c|c|c|c|c|c|c|c|c|c|c|c|c|c|c|c|c|}
\hline & $\mathrm{JP}$ & UK & $\mathrm{AU}$ & $\mathrm{DE}$ & HK & MY & $\mathrm{NO}$ & US & BR & FI & $\mathrm{CA}$ & PT & $\mathrm{CH}$ & $\mathrm{KR}$ & IT & MX & $\mathrm{AR}$ \\
\hline \multirow[t]{2}{*}{$\begin{array}{l}\text { You were involved in research projects } \\
\text { with faculty or senior researchers }\end{array}$} & 21 & 36 & 40 & 41 & 42 & 44 & 44 & 50 & 52 & 54 & 56 & 56 & 58 & 59 & 67 & 71 & 86 \\
\hline & $\mathrm{JP}$ & $\mathrm{KR}$ & $\mathrm{CH}$ & PT & IT & UK & HK & $\mathrm{AU}$ & $\mathrm{DE}$ & FI & NO & BR & MX & $\mathrm{CA}$ & US & MY & $\mathrm{AR}$ \\
\hline $\begin{array}{l}\text { You served on an institutional or } \\
\text { departmental (unit) committee }\end{array}$ & 3 & 5 & 8 & 9 & 11 & 12 & 13 & 18 & 18 & 19 & 24 & 27 & 28 & 29 & 31 & 32 & 38 \\
\hline
\end{tabular}


Table 8. Number of higher education institutions employed in since first degree/ highest degree (median). Mobility between institutions

CH IT MX MY PT AR AU BR DE HK JP KR NO UK CA US FI

$\begin{array}{lllllllllllllllll}\text { Since first } & 1 & 1 & 1 & 1 & 1 & 2 & 2 & 2 & 2 & 2 & 2 & 2 & 2 & 2 & 3 & 3\end{array}$
degree

$\begin{array}{lllllllllllllllll}\text { Since highest } & 1 & 1 & 1 & 1 & 1 & 2 & 2 & 1 & 2 & 2 & 1 & 2 & 2 & 2 & 2 & 2\end{array}$
degree

regulation of academic labour markets found in those countries participating in the CAP study. These conditions vary according to the history, resourcing and governance of the different national higher education systems. ${ }^{16}$ Academics can be civil servants, public employees or private employees and this can determine whether their employment is subject to public law (civil servants) or private law (employees). In several continental European countries, for example, academics are public officials subject to state law, often with the privilege of tenure (i.e. protection against dismissal) but without the rights to collective bargaining between their representatives (usually, unions) and their employers, or the ultimate sanction of strike action. In many other countries, however, academics have the legal status of an employee and a contract of employment that regulates their working conditions. In the UK, for example, even though higher education institutions are funded mainly through public expenditure and there is only one private university, these contracts are based on private law. Tenure was abolished in 1988 in universities, and had never applied in the polytechnics. A number of countries have recently transferred responsibility for the employment of academics from the state to institutions, including Italy and Japan, and this is having a significant impact on the nature and conditions of academic work. ${ }^{5}$

Within some national higher education systems - the US and Japan, for example - there is a mixture of public and private institutions and, although academics in both types may be employees subject to private law, the method of regulating the employment relationships may differ. For those working in public institutions, collective bargaining tends to predominate, while those in the private sector may be subject to the regulations of their employing institution, which can vary from one to another. ${ }^{17}$ Further disparity may be introduced through forms of individual bargaining between a member or groups of academic staff and an employer, whether a private or public institution. ${ }^{18}$ There is also evidence that the interpretation of tenure may be changing, even in those countries where it is 
enshrined in law. The grounds for dismissal that may be proscribed, the categories of academic staff that are eligible for this status and the introduction of redeployment, voluntary redundancy and early retirement can all have an effect on the strength of tenure in practice. ${ }^{19}$

\section{Modes and duration of employment}

The CAP survey provides rich data on the modes and duration of employment of the respondents in the different countries. Because the CAP dataset has not yet been weighted, these data will need to be compared with statistical analyses of the national academic populations in each country. In a few countries, for example, part-time academics were not included in the sample, in some cases because of the difficulty of contacting them. The data from these countries have not been included in Table 9. Nevertheless, the remaining figures provide some indication of the degree to which the expansion and marketisation of higher education has introduced more varied and flexible employment conditions, particularly in the form of part-time and fixed-term contracts.

In the majority of countries, at least four out of every five respondents reported being employed full-time and, for nearly half of these nations, the proportion was closer to 19 out of every 20. It is possible, however, that full-time academics were more likely to respond to the survey than those on part-time contracts, due to being more accessible and having greater opportunity to complete the questionnaire. In the UK, for example, the official national data source reported the proportion of full-time academics as $67 \%$ in $2006 / 07^{20}$ compared with the CAP response of $89 \%$. Academic respondents from Asian countries were slightly more likely to report being employed full-time than most European and Englishspeaking countries. However, these responses also appear to overstate the proportion of the full-time academic population in Japan. ${ }^{21,22}$

Table 9. Mode of employment of respondents, selected countries (\%)

\begin{tabular}{|c|c|c|c|c|c|c|c|}
\hline & AR & $\mathrm{BR}$ & $\mathrm{DE}$ & $\mathrm{AU}$ & UK & PT & HK \\
\hline Full-time & 51 & 55 & 82 & 86 & 89 & 94 & 95 \\
\hline Part-time employed & 43 & 12 & 14 & 13 & 9 & 3 & 3 \\
\hline $\begin{array}{l}\% \text { of part-time academics working } \\
\text { more than } 50 \% \text { of full-time }\end{array}$ & 50 & 68 & 95 & 82 & 80 & 38 & 64 \\
\hline $\begin{array}{l}\% \text { of part-time academics working } \\
\text { less than } 50 \% \text { of full-time }\end{array}$ & 50 & 32 & 5 & 18 & 19 & 62 & 36 \\
\hline $\begin{array}{l}\text { Part-time with payment according to } \\
\text { work tasks }\end{array}$ & 1 & 32 & 0 & 0 & 1 & 0 & 3 \\
\hline Other & 5 & 1 & 4 & 0 & 1 & 3 & 0 \\
\hline
\end{tabular}


Table 10. Contract duration: percentage of respondents, by country

\begin{tabular}{|c|c|c|c|c|c|c|c|c|c|c|c|c|c|c|c|c|c|}
\hline Permanently employed & $\mathrm{KR}$ & $\mathrm{AR}$ & $\mathrm{CH}$ & HK & $\mathrm{DE}$ & FI & PT & AU & $\mathrm{BR}$ & US & $\mathrm{CA}$ & $\mathrm{JP}$ & $\mathrm{NO}$ & $\mathrm{MX}$ & UK & MY & IT \\
\hline & 5 & 6 & 28 & 34 & 36 & 38 & 48 & 50 & 56 & 58 & 71 & 75 & 75 & 79 & 84 & 85 & \\
\hline \multirow[t]{2}{*}{ Continuously employed } & NO & $\mathrm{CA}$ & MY & PT & HK & UK & FI & MX & AR & $\mathrm{AU}$ & US & $\mathrm{JP}$ & $\mathrm{DE}$ & $\mathrm{BR}$ & $\mathrm{CH}$ & $\mathrm{KR}$ & IT \\
\hline & 1 & 2 & 3 & 3 & 7 & 8 & 10 & 10 & 12 & 12 & 12 & 15 & 25 & 38 & 49 & 52 & \\
\hline \multirow[t]{2}{*}{ Fixed Term } & $\mathrm{BR}$ & JP & MY & UK & MX & $\mathrm{CH}$ & $\mathrm{NO}$ & CA & US & FI & $\mathrm{AU}$ & $\mathrm{DE}$ & $\mathrm{KR}$ & PT & $\mathrm{HK}$ & $\mathrm{AR}$ & IT \\
\hline & 5 & 9 & 9 & 9 & 11 & 22 & 22 & 27 & 29 & 36 & 38 & 38 & 43 & 45 & 55 & 72 & \\
\hline \multirow[t]{2}{*}{ Other } & $\mathrm{KR}$ & UK & AR & $\mathrm{AU}$ & $\mathrm{BR}$ & $\mathrm{CA}$ & $\mathrm{CH}$ & $\mathrm{DE}$ & JP & MX & $\mathrm{NO}$ & US & HK & MY & PT & FI & IT \\
\hline & 0 & 0 & 1 & 1 & 1 & 1 & 1 & 1 & 1 & 1 & 2 & 2 & 3 & 3 & 4 & 15 & \\
\hline
\end{tabular}


Table 11. Research collaboration: percentage of respondents, by country

\begin{tabular}{|c|c|c|c|c|c|c|c|c|c|c|c|c|c|c|c|c|c|}
\hline & FI & NO & AR & MY & $\mathrm{KR}$ & $\mathrm{BR}$ & MX & IT & $\mathrm{HK}$ & $\mathrm{JP}$ & $\mathrm{DE}$ & UK & PT & $\mathrm{CA}$ & $\mathrm{CH}$ & US & $\mathrm{AU}$ \\
\hline \multirow{2}{*}{$\begin{array}{l}\text { Working individually/without } \\
\text { collaboration on any research projects }\end{array}$} & 16 & 22 & 31 & 31 & 36 & 38 & 38 & 47 & 51 & 51 & 58 & 59 & 61 & 68 & 69 & 74 & 79 \\
\hline & PT & $\mathrm{JP}$ & $\mathrm{CH}$ & $\mathrm{DE}$ & $\mathrm{KR}$ & MX & $\mathrm{BR}$ & US & IT & UK & HK & MY & $\mathrm{CA}$ & NO & $\mathrm{AR}$ & FI & $\mathrm{AU}$ \\
\hline \multirow[t]{2}{*}{ Collaborators on any research projects } & 44 & 62 & 73 & 74 & 75 & 76 & 78 & 78 & 82 & 82 & 84 & 85 & 86 & 87 & 88 & 88 & 89 \\
\hline & $\mathrm{CH}$ & $\mathrm{JP}$ & MX & PT & HK & MY & $\mathrm{BR}$ & US & $\mathrm{KR}$ & NO & AU & UK & AR & FI & $\mathrm{DE}$ & $\mathrm{CA}$ & IT \\
\hline \multirow{2}{*}{$\begin{array}{l}\text { Collaborate with persons at other } \\
\text { institutions in your country }\end{array}$} & 37 & 51 & 54 & 54 & 55 & 55 & 61 & 61 & 65 & 66 & 67 & 67 & 69 & 69 & 70 & 72 & 77 \\
\hline & $\mathrm{CH}$ & JP & $\mathrm{KR}$ & $\mathrm{BR}$ & MY & PT & US & MX & AR & $\mathrm{DE}$ & AU & IT & $\mathrm{HK}$ & UK & $\mathrm{CA}$ & NO & FI \\
\hline Collaborate with international colleagues & 13 & 24 & 29 & 30 & 32 & 32 & 33 & 35 & 47 & 58 & 59 & 59 & 60 & 61 & 66 & 67 & 70 \\
\hline
\end{tabular}


Argentina (51\%) and Brazil (55\%) had far fewer respondents employed fulltime than in the other countries. Indeed, in Argentina, national data indicate that part-time academics now predominate, with only $13 \%$ working full-time at 40 hours per week, approximately $10 \%$ at 25 hours per week and $67 \%$ at 10 hours per week. This is due to expansion of the academic population, largely in the public sector, in response to growing student demand. ${ }^{23}$ Brazil and Mexico also participated in the earlier Carnegie study and it is interesting to compare the results of the two surveys for these two Latin American countries. While the expanded private and philanthropic institutions in Brazil now account for the majority of academics without contracts (let alone part-time contracts), ${ }^{24}$ the Mexican Government's improvement programme has led to an increase in the number of full-time appointments between the two surveys. ${ }^{25}$ In 2007, nearly a third of respondents from Brazil reported being employed part-time with payment according to work tasks. Most of those working in private institutions in Brazil are likely to be working part-time, usually in the evenings, and will have no career plans or job security. Hardly any academics from other countries reported being employed part-time with payment according to work tasks.

For most countries with significant numbers of part-time academics in their sample, the mean percentage of the full-time equivalence was close to $50 \%$, with only Argentina reporting substantially less than this. This is backed-up by national data. ${ }^{23}$ (The percentage figures for China and Malaysia are higher, but the proportions of academics on part-time contracts are so small as to be insignificant.)

Only in Argentina and Hong Kong did a majority of respondents report being on fixed-term contracts (Table 10). In Argentina, this is a consequence of the 'test mechanism' for recruiting to an academic post, which is awarded for a fixed duration, at the end of which an open contest is called to refill the position. ${ }^{23}$ Increasingly, though, universities are introducing renewable contracts, with the effect that over two thirds of respondents reported fixed term employment with permanent/continuous prospects (tenure track). Competition for tenured positions is also highly competitive in Hong Kong, although 'there is a recognized academic career path and reasonable security of employment'. ${ }^{26}$ Nevertheless, 28\% still reported being employed for a fixed duration without permanent prospects. The country with the highest proportion of respondents in this latter category, however, was Germany, with 33\%, largely made up of junior or assistant professors or wissenschaftliche Mitarbeiter, who can spend long periods of dependence and uncertainty before becoming secure and independent scholars. ${ }^{27}$ Even in countries, such as in North America and the UK, where the majority of existing academics are permanently employed, newer recruits may be less likely to be awarded permanent contracts because of recent policies on 'flexible' employment. 
Pay

It is not surprising that those respondents from mature higher education systems (Hong Kong, Japan, North America and Europe) reported earning the highest salaries and those from emerging/rapidly expanding systems (Latin America, China, Malaysia and Korea) the lowest (Figure 1). Given the variations in costs of living, inflation, exchange rates, other possible benefits of employment (such as pensions, loans, travel and accommodation in some countries), it is difficult to draw firm conclusions on the basis of these data. However, the recent CIHE (Boston College $^{28}$ ) international comparison of academic salaries calculates the overall average monthly salaries of nine of the 17 countries in the CAP study and normalises these using the World Bank's purchasing power parity measures to produce a US dollar (\$) value. The rank order in Figure 2 is similar to the CAP findings (except Japan is ranked lower and Australia higher) although the salary levels are different to the CAP survey results due to normalisation. According to this analysis, overall average monthly salaries - for the nine CAP countries included - range from $\$ 1182$ in China to $\$ 6548$ in Canada. This produces a mean average of $\$ 4143$ per month for these nine CAP countries, with Canadian academics earning on average 5.5 times more than their Chinese counterparts.

The CIHE study is an example of a large scale comparator to the CAP data looking at approximately the same time frame and covering a majority of the same countries, but with normalisation for purchasing power. The authors of the CIHE study warn that these figures are not weighted according to the proportion

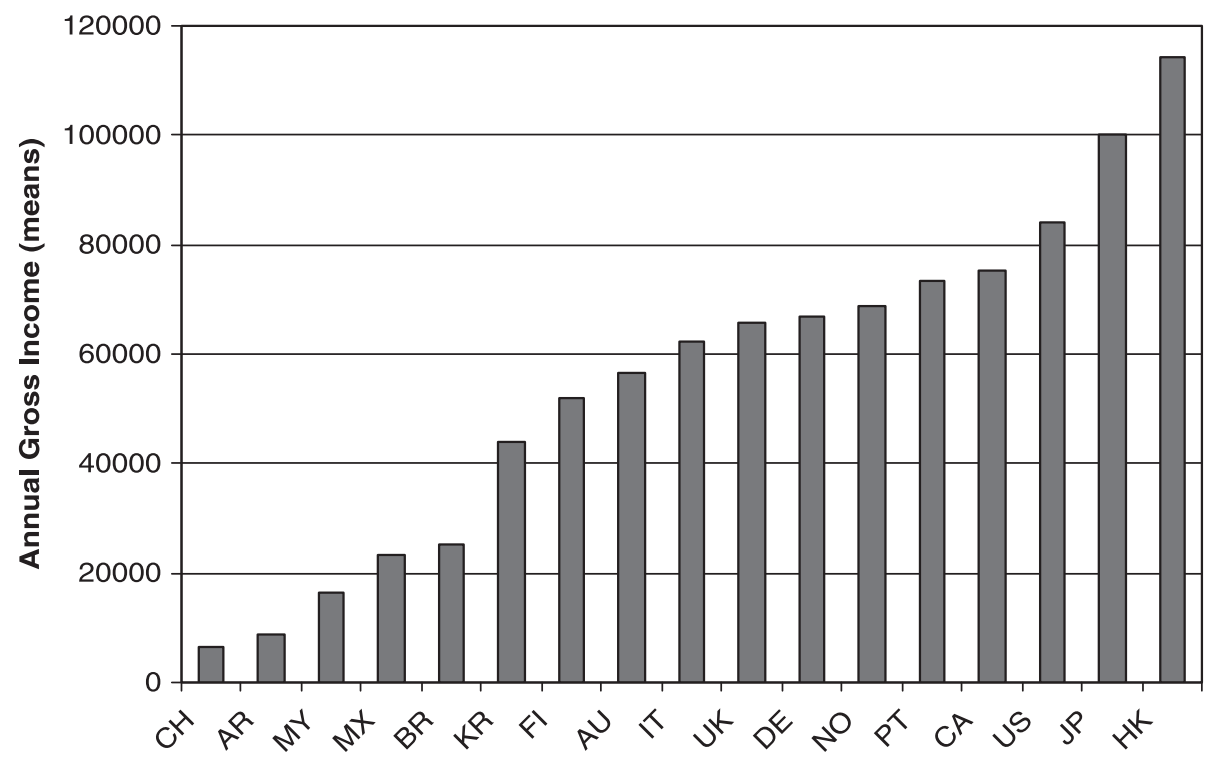

Figure 1. Annual Gross Income in US\$, by country (means). 


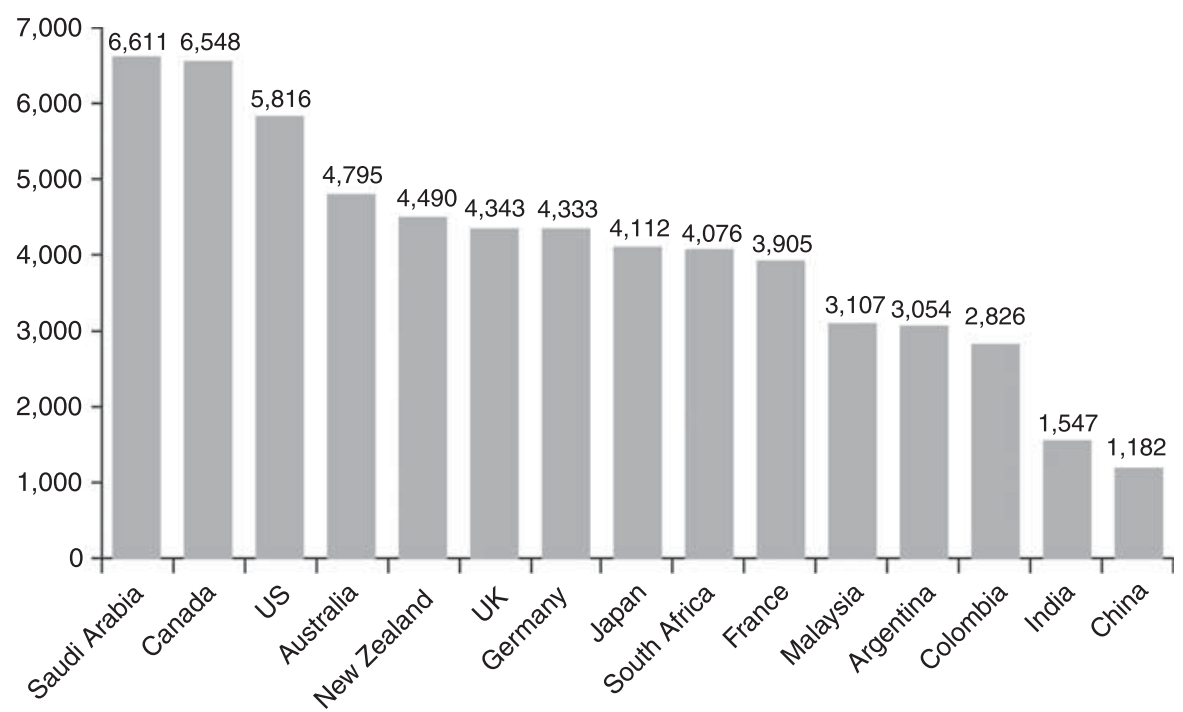

Figure 2. Overall Average Monthly Salaries in US\$ in $2005 / 06$, by country. ${ }^{28}$

of academics on each pay level. In some countries, such as the US, the proportion of those reaching the professorial grade is much higher than in the UK and Germany, for example. Likewise, as the CAP data are not weighted in order to achieve representative proportions of respondents on each grade, they can only offer an approximate indicator of the comparative salary levels among the CAP countries. Furthermore, salary levels on comparable grades may differ between public research universities and private institutions in the same country. The CAP survey also asked respondents about income from other concurrent employers and from self-employment. Those from Brazil needed to supplement their income from other employment to the highest level among all the countries in the study. However, US academics reported earnings from self-employment in excess of a quarter of their main salary - nearly four times more than the next highest country, Italy.

It is also worth pointing out that, in those countries with relatively high levels of remuneration, the intrinsic rewards of an academic role - such as a high degree of autonomy, interesting work and the esteem of other scholars - may be as important as, or more important than, pay and status. ${ }^{19}$ Senior academics, and especially those who manage to raise substantial research funds, may be able to negotiate increased control over their workloads and, to some extent, the nature of their activities. This diversity in working conditions across the CAP study makes comparison difficult within countries, let alone between national systems. The CIHE study, for example, found that differences between the top and entry level academic salaries within systems were not necessarily related to a country's economic development, and that pay differences (as distinct from overall academic 
salary levels) in South Africa were greater than in North America, and greater in Argentina than in Germany and France. ${ }^{28}$

\section{Support for academic work and research collaboration}

Given the importance of non-pecuniary rewards to academics, it is essential to consider the broader circumstances of academic work in this assessment of employment conditions.

\section{Support for academic work}

CAP respondents were asked to rate the levels of institutional support for academic work, including facilities, resources and personnel. Across all countries, the highest proportions of respondents rated telecommunications, libraries and computer facilities as excellent or very good. Research funding and research and teaching support staff tended to attract the lowest proportions of excellent or very good ratings. Academics in Argentina, Japan and Korea seemed to be less likely to be satisfied with institutional support for academic work, and those in Hong Kong, Norway, Germany and Finland were most satisfied. Compared with the earlier Carnegie study, academics in Hong Kong were also among the most satisfied in 1992, and Japan and Korea among the least satisfied. ${ }^{4}$ Today, computer facilities and library resources were viewed most favourably in many countries. Generally, in 2007, in those countries where there were consistent differences, senior staff were more likely to be satisfied with the institutional support they receive than their junior colleagues.

\section{Research collaboration}

The CAP study reveals the increasingly international and collaborative nature of the research carried out in higher education institutions. Developments in information and communications technologies - as well as cheaper and more accessible air travel - will certainly have made international cooperation more feasible. In some regions, multinational funding of research, such as the Framework Programme in the European Union, will also have contributed to this trend, together with national evaluative approaches and funding mechanisms that privilege and reward internationally recognised research, such as the UK Research Assessment Exercise. It would be interesting to investigate whether the proportions collaborating would be higher if only respondents who identify themselves as being active in research and publication were included in the sample.

Generally, it seems that respondents from all countries are more likely to be collaborating with others on research projects than working individually and alone (Table 11). In all but one country, China, over half the respondents were collaborating with colleagues at other institutions within the same country. In half the countries in the study, more than $50 \%$ of respondents reported collaborating with 
international colleagues. Academics from Finland and Norway were most likely to collaborate with international colleagues and least likely to work on their own. In small but developed countries such as these, scholars in most disciplines will seek international visibility in order to be recognised and respected, even in their own country, which may be seen as too small or restricted a territory on which to build a scholarly reputation. ${ }^{5}$

Larger countries, such as Germany or France, may offer academics a more equal choice between national or international collaboration. However, few respondents in Japan and China reported collaborating with international colleagues and the same factors that discourage students from these countries from studying abroad may also be inhibiting them from working with foreign researchers. Only a third of US respondents reported collaborating with international colleagues, making that country 11 th out of the 17 in the dataset. Just five per cent of respondents from the US had co-authored a publication with colleagues located in other (foreign) countries - the smallest proportion except for China - and only $7 \%$ had published in a foreign country - the lowest of all countries in the study. This insularity is also reflected in current citation patterns of US academics, and the finding from the 1992 Carnegie survey that far fewer Americans than respondents from other countries believed that a scholar must read books and journals published abroad to keep up with scholarly developments. ${ }^{29}$

\section{Concluding comments}

The early career paths and employment conditions of academics are primarily influenced by the history, resourcing and governance of individual national higher education systems. The systems determine the modes of preparation and training for the academic professions, recruitment practices, employment legislation, labour relations, forms and patterns of remuneration and the status and security of different segments of the profession. However, as common forces begin to transform these systems - expansion, massification, internationalisation, globalisation, marketisation - we can begin to assess the balance of national particularities and global trends, of similarities and differences as experienced by academics in these systems and, in some cases, when moving between them. The CAP study provides insights into these similarities and differences, but the data need to be interpreted carefully in each national context as well as in their entirety before coming to firm comparative conclusions. This paper has made a start on this, but further analysis is required, by those with a deep understanding of each country's system and its particular circumstances as well as those willing to take broader, regional and global, overviews. The impact of regional developments, such as the creation of the European Higher Education Area, the European Research Area and increasing research and development targets also 
needs to be assessed. Shifts in the flows - or circulation - of academics and students between and within the Southern and Northern hemispheres should be monitored for their impacts on developing countries' higher education systems and national capacities. The overall demand for, and mobility of, highly qualified expertise in all types of 'knowledge industries' may also impinge on higher education's capacity to attract - and retain - the 'brightest minds'. In conclusion, we highlight some connections between the aspects of employment reviewed in this paper and raise a number of questions for further examination.

First, the importance of national context is underlined when seeking to explain differences in levels of research cooperation between national respondents to the CAP study. It is reasonable to posit a link between the international mobility of academics during training and preparation for the profession and their current level of international research collaboration. It could be argued that contact with academics and students in a different national setting, and exposure to indigenous knowledge, possibly in a different language and culture, during a formative period in an individual's career, might develop a greater propensity to future international intellectual exchange. This may also be true of academics previously or currently working abroad. Indeed, several countries with a relatively high proportion of respondents who obtained a doctorate outside their country of current employment also reported high levels of collaboration with international colleagues. Hong Kong, Canada, Norway and Australia would be examples of this. Conversely, Japan, the US, China and Brazil report lower proportions of foreign doctorates and lower levels of international collaboration than other CAP countries. However, some countries with lower proportions of foreign doctorates also record higher levels of collaboration with foreign researchers, such as Finland, the UK, Italy and Germany. And some national systems with higher proportions of foreign doctorates are also characterised by lower levels of international research cooperation, such as Malaysia, Korea, Mexico and Portugal. In all countries, but perhaps particularly in the latter cases, a more detailed national analysis and interpretation is needed of whether, and under what circumstances, this link can be made. In particular, the different characteristics of the sciences, social sciences and humanities and the condition of national academic labour markets may have an effect on international mobility and collaboration.

Secondly, it also seems likely that the introduction of greater flexibility in academic employment conditions and the reform of traditional career paths will expand the potential for the international circulation of academic labour. Increasing fixedterm employment, including postdoctoral places and short-term academic visits, may open up opportunities for mobile academics. However, these opportunities are more likely to be for researchers than those seeking positions with responsibility for teaching and service, as well as research. As such, they are linked with the new divisions of labour between, for example, those on research contracts and those 
employed only to teach. The opportunities are also more likely to be taken up by junior staff at a relatively early stage of their career who wish to broaden their experience and increase their value in the academic marketplace in the country of their host institution, their home country or elsewhere. The majority of regional schemes, for example, in Europe, are aimed at early-career researchers and are even closed to more experienced academics. These developments raise questions about the impact of increased international circulation of young contract researchers on the employment conditions of mid-career, less mobile academics with families, their career paths and progression, the fragmentation of academic activities and the increasing management and evaluation of academic work. ${ }^{5}$

Finally, it is clear from the data on academic inflows that institutional support for study (e.g. scholarships), employment (e.g. salaries) and research (e.g. facilities and funding) play an important part in attracting highly qualified academics from abroad, as well as from within a country. But there is a range of factors and issues beyond institutional control that can either facilitate or constrain mobility (or both at the same time): for example, similarities or differences between countries in pension schemes, national systems of social security and childcare provision (which can present barriers to female researchers in particular $^{30}$ ); information or the lack of information about these arrangements, the funding and other support available to facilitate movement, the recruitment procedures used in different countries and actual vacancies; ${ }^{31}$ language and cultural differences and the ascendancy of the English language in education and research; differences in salaries, status, workloads, career patterns, promotion procedures and tenure tracks; ${ }^{32}$ immigration policy and legislation on highly qualified workers, covering visas and work permits and the time and costs attached to applying for and obtaining these, ${ }^{7}$ including arrangements for foreign doctoral graduates wishing to take up postdoctoral or other academic positions.

These and other issues and questions need to be explored further, through the CAP survey data and other studies, to establish the changing career paths and employment conditions of academics in different national settings and the extent to which there is - or could be - a truly international academic profession.

\section{Acknowledgement}

The authors acknowledge the support of the Fondazione Compagnia di San Paolo.

\section{References and Notes}

1. J. Kubler and C. DeLuca (2006) Trends in Academic Recruitment and Retention: A Commonwealth perspective (London: Association of Commonwealth Universities). 
2. L. E. Rumbley, I. F. Pacheco and P. G. Altbach (2008) International Comparison of Academic Salaries: An Exploratory Study (Boston, MA: Boston College, Centre for International Higher Education).

3. E. L. Boyer, P. G. Altbach and M. J. Whitelaw (1994) The Academic Profession: An International Perspective (Princeton, NJ: Carnegie Foundation for the Advancement of Teaching).

4. P. G. Altbach (ed.) (1996) The International Academic Profession: Portraits of Fourteen Countries (Princeton, NJ: The Carnegie Foundation for the Advancement of Teaching).

5. J. Enders and C. Musselin (2008) Back to the future? The academic professions in the 21st century. In: OECD, Higher Education to 2030, Volume 1: Demography, Centre for Educational Research and Innovation (Paris: Organisation for Economic Co-operation and Development), pp. $125-150$.

6. S. Marginson (2008) Global field and global imagining: Bourdieu and worldwide higher education. British Journal of Sociology of Education, 29(3), pp. 303-315.

7. K. Tremblay (2005) Academic mobility and immigration. Journal of Studies in International Education, 9(3), pp. 196-228.

8. A. R. Welch (1997) The peripatetic professor: the internationalisation of the academic profession. Higher Education, 34(3), pp. 323-345.

9. T. Kim (2008) Higher education reforms in South Korea: public-private problems in internationalising and incorporating universities. Policy Futures, 6(5), pp. 558-568.

10. H. Casanova-Cardiel (2005) Mexico. In: International Handbook of Higher Education, edited by J. Forest and P. Altbach (Dordrecht, The Netherlands: Springer), pp. 881-898.

11. G. A. Postiglione and H. H. Hayes Tang (2008) A preliminary review of the Hong Kong CAP data. In: The Changing Academic Profession in International Comparative and Quantitative Perspectives: Report of the International Conference on the Changing Academic Profession Project, 2008 (Hiroshima: Research Institutes for Higher Education, Hiroshima University and Hijiyama University), pp. 227-249.

12. B. M. Kehm (2007) The changing role of graduate and doctoral education as a challenge to the academic profession: Europe and North America compared. In: Key Challenges to the Academic Profession, edited by M. Kogan and U. Teichler (Kassel, Germany: International Centre for Higher Education Research), pp. 111-124.

13. P. Altbach (2006) Doctoral education: present realities and future trends. In: International Handbook of Higher Education, edited by J. Forest and P. Altbach (Dordrecht, The Netherlands: Springer), pp. 65-81.

14. The doctoral degree was introduced in Italy in the early $1980 \mathrm{~s}$, and for many years the entrance to doctoral training was only by competition with the winners entitled to receive a fellowship. This has changed in recent years, but it explains why there is a relatively low proportion of Italian respondents with a doctoral degree and a very high percentage reporting receiving a fellowship during doctoral training. 
15. A. Yamanoi (2006) Japanese academic marketplace and academic productivity. In: Reports of Changing Academic Profession Project Workshop on Quality, Relevance, and Governance in the Changing Academia: International Perspectives (Hiroshima: Research Institute for Higher Education, Hiroshima University), pp. 21-35.

16. D. Farnham (1999) Managing universities and regulating academic labour markets. In: Managing Academic Staff in Changing University Systems: International Trends and Comparisons, edited by D. Farnham (Buckingham: Society for Research into Higher Education/Open University Press), pp. 3-31.

17. In the US, collective bargaining predominates in public 2-year and 4-year institutions but not in the university sector. Most of the public universities that are unionised are in the northeast and the Midwest of the country. This is because unionisation of public employees requires enabling legislation by the individual states. The South and the west of the country are too libertarian for unionisation.

18. J. Enders (2001) Between state control and academic capitalism: a comparative perspective on academic staff in Europe. In: The Academic Staff in Europe: Changing Contexts and Conditions, edited by J. Enders (Westport, CT: Greenwood Press), pp. 1-23.

19. J. Enders (2006) The academic profession. In: International Handbook of Higher Education, edited by J. Forest and G. Altbach (Dordrecht, The Netherlands: Springer), pp. 5-21.

20. HESA (2008) Resources of Higher Education Institutions 2006/07 (Cheltenham: Higher Education Statistics Agency).

21. A. Arimoto (2006) The changing academic profession in Japan: its origins, heritage and current situation. In: Reports of Changing Academic Profession Project Workshop on Quality, Relevance, and Governance in the Changing Academia: International Perspectives (Hiroshima: Research Institute for Higher Education, Hiroshima University), pp. 183-194.

22. A. Arimoto (2007) Japan: origins, history and transition to a universal higher education system. In: The Changing Conditions for Academic Work and Careers in Select Countries, edited by W. Locke and U. Teichler (Kassel, Germany: International Centre for Higher Education Research), pp. 113-126.

23. M. Marquina and N. F. Lamarra (2008) The academic profession in Argentina: characteristics and trends in the context of a mass higher education system. In: The Changing Academic Profession in International Comparative and Quantitative Perspectives: Report of the International Conference on the Changing Academic Profession Project (Hiroshima: Research Institutes for Higher Education, Hiroshima University and Hijiyama University), pp. 363-387.

24. S. Schwartzman and E. Balbachevzky (2009) The academic profession in a diverse institutional environment: converging or diverging values and beliefs? Paper given at the International Conference on the Changing Academic Profession Project: The Changing Academic Profession Over 
1992-2007: International, Comparative and Quantitative Perspectives, January 2009, Hiroshima University, Japan.

25. J. F. Galaz-Fontes, L. E. Padilla-Gonzalez, M. Gil-Antón, J. J. SevillaGarcía, J. L. Arcos-Vega, J. Martínez-Stack, S. Martínez-Romo, L. Jiménez-Loza and M. E. Barrera-Bustillos (2008) Mexican academics at the turn of the twenty-first century: who are they and how they perceive their work, institutions and public policies (a preliminary analysis). In: The Changing Academic Profession in International Comparative and Quantitative Perspectives: Report of the International Conference on the Changing Academic Profession Project (Hiroshima: Research Institutes for Higher Education, Hiroshima University and Hijiyama University), pp. 345-361.

26. G. A. Postiglione (2006) The Hong Kong Special Administrative Region of the People's Republic of China: context, higher education, and a changing academia. In: Reports of Changing Academic Profession Project Workshop on Quality, Relevance, and Governance in the Changing Academia: International Perspectives (Hiroshima: Research Institute for Higher Education, Hiroshima University), pp. 97-114.

27. U. Teichler and O. Bracht (2006) The academic profession in Germany. In: Reports of Changing Academic Profession Project Workshop on Quality, Relevance, and Governance in the Changing Academia: International Perspectives (Hiroshima: Research Institute for Higher Education, Hiroshima University), pp. 129-150.

28. L. E. Rumbley, I. F. Pacheco and P. G. Altbach (2008) International Comparison of Academic Salaries: An Exploratory Study (Centre for International Higher Education, Boston, MA: Boston College).

29. P. Altbach (2007) Academic challenges: the American professoriate in comparative perspective. In: The Professoriate: Profile of a Profession, edited by A. Welch (Dordrecht: Springer), pp. 133-145.

30. UUK (2008) Researcher Mobility in the European Research Area: Barriers and Incentives, Research Report (London: Universities UK). http://www.universitiesuk.ac.uk/Publications/Documents/Researcher_ mobility.pdf

31. C. Musselin (2004) Towards a European academic labour market - some lessons drawn from empirical studies on academic mobility. Higher Education, 48(1), 55-78.

32. C. Musselin (2005) European academic labor markets in transition. Higher Education, 49(1/2), 135-154.

\section{About the Authors}

Alice Bennion is a Research Associate, Centre for Higher Education Research and Information (CHERI) at the Open University in the United Kingdom (UK). Since joining CHERI in 2007 she has been working alongside William Locke analysing data and contributing to publications relating to the international study of the 'Changing Academic Profession', including chapters for books and journal articles. 
In addition, she has worked on the nationally funded project 'Higher Education and Regional Transformation' (HEART) which is investigating the complex relationship between 'disadvantaged' communities and their local higher education institutions. Bennion recently completed her doctorate at the Institute of Education, University of London. Her doctoral research examines changing family forms and contemporary family life with a particular focus on the relationship between home and school. This work highlights the current contradictions existing within modern family life and emphasises the inherent gendered assumptions that surround parenting.

William Locke is Assistant Director and Principal Policy Analyst, Centre for Higher Education Research and Information (CHERI) at the Open University in the United Kingdom. He is directing the UK part of the international study of the Changing Academic Profession, which is investigating the nature and extent of the changes experienced by the academic profession in recent years in more than 20 countries. William is co-editor, with Ulrich Teichler, of The Changing Conditions for Academic Work and Careers in Select Countries, published by the International Centre for Higher Education Research, Kassel University. He has published several papers on the academic profession in the UK. William has undertaken research and published on a number of policy issues, including: the higher education research-policy nexus; the role of intermediary bodies in higher education; student engagement; university rankings and their impact on higher education institutions; English higher education policy; and conceptions of excellence in teaching and student learning. He is also the author of a report on graduates' retrospective views of their courses as part of the European Commission funded project, REFLEX: the flexible professional in the knowledge society. Forthcoming publications include a co-edited book on the governance and management of universities and a chapter on markets in UK higher education. William has spoken at international conferences in Australia, Canada, China, Japan, the United States and throughout Europe.

Previous to working for CHERI William Locke was Deputy Director, Policy Development, Universities UK (UUK) - the vice chancellors' representative organization - until 2006 where he led on longer term strategy, and policy on learning, teaching and assessment; recording student achievement; student services; widening participation; and employability and careers education. Prior to joining UUK, he was Head of Teaching and Learning Development at the University of Sussex in the UK. 